\title{
FRACTURE TOUGHNESS TESTING OF NICKEL ALLOYED PERMANENT MOULDED AUSTEMPERED DUCTILE IRON USING SINGLE EDGE NOTCH BENDING SPECIMENS
}

\author{
RAGHAVENDRA J. V \& K. NARASIMHAMURTHY \\ Assistant Professor, Department of Mechanical Engineering, Jyothy Institute of Technology, \\ Bangalore, Karnataka, India
}

Professor, Department of Mechanical Engineering, Atria Institute of Technology, Bangalore, Karnataka, India

\begin{abstract}
Laboratory Fracture Toughness test have been reported on Permanent moulded Austempered Ductile Iron (PMADI) with Nickel as alloying element utilizing conventional austempering process. The Nickel additions were made at different levels from 0.5 wt \% to 2 wt \% in steps of 0.5\%. Single edge notch bending specimens (SENB) austempered at $320^{\circ} \mathrm{C}$ for $120 \mathrm{Min}$ were subjected to three point bending test to evaluate the plane strain fracture toughness (KIC). From the experimental results, It was found that the samples containing $1.5 \%$ Nickel exhibit superior fracture toughness characteristics in comparison with $0.5 \%, 1 \%$ and $2 \%$ Nickel content. The effect of crack length to width $(a / w)$ ratio on fracture toughness is also discussed. The fracture toughness of $1.5 \%$ bearing Nickel sample showed an increase of about $17 \%$ more in comparison with unalloyed PMADI sample austempered under similar conditions. Finite element analysis using ANSYS were carried out and the stress distribution was found to be maximum around the region of crack. The results were construed based on the analysis of retained austenite content, distribution of Bainite and the matrix microstructure of nickel alloyed PMADI samples.
\end{abstract}

KEYWORDS: Permanent Moulded, Ductile Iron, Fracture Toughness, Austempering Process, ANSYS

Received: Jun 09, 2020; Accepted: Jun 29, 2020; Published: Sep 21, 2020; Paper Id.: IJMPERDJUN20201356

\section{INTRODUCTION}

Austempered Ductile Iron (ADI) belongs to ductile family of Iron and is considered as a novel engineering material in recent years because of its superior mechanical properties. ADI is competing fiercely with steel alloys, forged steel and aluminium alloys in terms of mechanical properties, manufacturing cost, physical properties and weight savings. [1]

The automobile industry is utilizing the potential benefits of austempering process and the typical examples include diesel engine timing gear, suspension brackets, gear housings, wheel hubs and sprockets. [2]

Ductile Iron (As cast) is subjected novel heat treatment process, where austenite is converted to Bainite with some retained austenite. ADI is microstructure sensitive and depends on heat treatment parameters like Austenitization, Austempering temperature and time. [3]

Seetharamu et al. [4] have reported that permanent moulded ADI castings have superior mechanical properties than sand moulded counter parts.

Conventionally ADI is cast in sand moulds and the utilization of Permanent Moulds offers better advantages in the form of higher production rate, excellent dimensional stability, and lower environmental 
pollution. Also, Graphite nodules are denser and finer than when ADI is cast in sand moulds. [5]

In permanent mould castings, the molten metal is poured into the die and flows at the force of gravity. The rate of heat transfer is higher in comparison with other moulds. [5]

A.A Abioye [6]studied the microstructure and mechanical characterization of low manganese ADI and concluded that, the austempering temperature and time has a significant effect on the microstructure and mechanical properties of ADI.

Jiwang Zhang et al. [7]highlightedthe influence of microstructure on mechanical properties of the ADI and concluded that, the heat treatment parameters have a significant effect on the microstructure and mechanical properties of ADI.

S.K Swain [8]highlighted the importance of XRD analysis to investigate the presence of retained austenite in ADI considering different austempering temperatures and time.

Ananda Hegde et al. [9] studied the mechanical characterization of manganese alloyed ADI and concluded that, the austenitization, austempering temperature and alloying element has a significant effect on the microstructure and mechanical properties of ADI.

Uma et al. [10] studied the mechanical properties and slurry erosive wear behaviour of nickel alloyed permanent moulded toughened austempered ductile iron (PMTADI) samples and concluded that, the samples containing $2 \%$ nickel shows a superior mechanical and wear characteristics in comparison with $1 \%$ and $2.5 \%$ nickel content.

NarasimhaMurthy et al. [11] studied the abrasion and erosion behaviour of manganese alloyed Permanent moulded austempered ductile iron (PMADI) and concluded that, the addition of more than $2 \% \mathrm{Mn}$ is detrimental for the mechanical properties.

Susil K Putatunda et al. [12] studied the fracture toughness of low manganese ADI considering austempering temperature and concluded that, the austempering temperature above $9820 \mathrm{C}$ has a detrimental effect on the fracture toughness.

The occurrence of flaws is not completely avoidable during the processing and fabrication of a component. Flaws may appear as cracks, voids, metallurgical inclusions, weld defects and design discontinuities. [13]

Fracture mechanics is used to evaluate the strength of a structure or component in the presence of a crack or flaw. Fracture Toughness is the ability of a material to bear the load in the presence of a crack. Stress Intensity factor $\left(\mathrm{K}_{\mathrm{I}}\right)$ is a unique design parameter which represents the magnitude of stress field severity near a crack tip. The componentfailure occurs when the stress Intensity factor $\left(\mathrm{K}_{\mathrm{I}}\right)$ exceeds the fracture toughness $\left(\mathrm{K}_{\mathrm{IC}}\right)$ of the material. Plane strain condition is specified by neglecting the effects of Plasticity. [13]

Ayman H Elsayed et al. [14]reported the mechanical properties, fracture toughness of bothalloyed and unalloyed ADI utilizing both conventional and two step austempering process and concluded that, the alloyed samples shows higher fracture toughness than un-alloyed ADI.

Peng-yue et al. [15] reported themechanical properties, fracture toughness of copper $(\mathrm{Cu})$ alloyed ADIconsidering two step austempering process and reported that, the fracture toughness of copper alloyed ADI monotonically increases with the addition of copper.

Ravishankar et al. [16]highlighted the importance of austempering process to achieve superior fracture toughness 
characteristics of ADI.

The literature review reveals that, the considerable research has been carried on evaluation of mechanical properties and wear characteristics of ADI. However, the role of nickel as alloying element to improve the fracture toughness characteristics of PMADI samples provided is scanty.

Experiments have been planned systematically to study the fracture toughness characteristics of nickel alloyed PMADI samples. The effect of a/w ratio on fracture toughness characteristics was also studied to avoid the catastrophic failure in the presence of a crack.

The demand for an alternate material to replace forged steel and steel alloys is now becoming a reality and hence, analyzing the better fracture toughness characteristics helps industries to enhance the life expectancy of Mining, Agricultural, Power plants and marine applications.

\section{EXPERIMENTAL PROCEDURE}

\subsection{Material}

The first step is Development of chill free spheroidal graphite (SG) iron (Grade - EN-GJS-400/15) with good nodularity poured into permanent moulds.

Permanent moulded ductile iron castings were melted in a coreless induction furnace of $50 \mathrm{~kg}$ capacity. Nickel additions were made to the melt in different levels (i.e. $0.5 \%, 1 \%, 1.5 \%$ and $2 \%$ ). $\mathrm{Fe}-\mathrm{Si}-\mathrm{Mg}$ alloy was used as nodularizer and ferrosilicon was used as inoculant.

The melt was poured at $1500-1530^{\circ} \mathrm{C}$ into a pre-heated $\left(220^{\circ} \mathrm{C}\right)$ grey cast iron mould of dimensions $550 \mathrm{~mm} \mathrm{X}$ $60 \mathrm{~mm} \times 60 \mathrm{~mm}$ to investigate the plane strain fracture toughness. The temperature at the surface of the mould was measured utilizing Thermo couples. The castings were allowed to cool at room temperature before being stripped out.

The final specimen was prepared into two pieces with a thickness of $25 \mathrm{~mm}$

Table.1 clearly indicates the chemical composition analysis for permanent moulded un-alloyed and Nickel alloyed Nodular Iron (As cast) utilizing optical emission spectrometer.

\begin{tabular}{|c|c|c|c|c|c|c|}
\hline \multicolumn{2}{|c|}{ Element in wt\% } & C & $\mathbf{S}$ & $\mathbf{S i}$ & Mg & $\mathbf{N i}$ \\
\hline \multirow{5}{*}{ Casting Designation } & Un-alloyed PMADI & 3.52 & 0.03 & 2.704 & 0.044 & - \\
\hline & PMADI $-0.5 \% \mathrm{Ni}$ & 3.28 & 0.03 & 2.54 & 0.04 & 0.54 \\
\hline & PMADI-1\% Ni & 3.32 & 0.03 & 2.58 & 0.04 & 1.05 \\
\hline & PMADI-1.5\% Ni & 3.36 & 0.03 & 2.7 & 0.04 & 1.53 \\
\hline & PMADI-2\% Ni & 3.30 & 0.03 & 2.6 & 0.04 & 2.02 \\
\hline
\end{tabular}

\subsection{Conventional Austempering Process}

The next step is unalloyed and Nickel alloyed as cast ductile iron is converted to austempered structure utilizing conventional Austempering process and the same is clearly depicted in Figure 1.

In the present work, Conventional Austempering process [Figure1] planned can be divided as follows

- Samples were austenitized to $912^{\circ} \mathrm{C}$ for 120 Min duration

- Samples were quenched in a salt bath furnace consisting a mixture of $45 \%$ sodium nitrate and $55 \%$ potassium nitrate by 
weight and subjected to Isothermal heat treatment at the austempering temperature of $320^{\circ} \mathrm{C}$ for 120 min duration

- Cooling to room temperature (Air cooled to room temperature)

Austenitizing time less than 120 Min duration was not selected because the complete transformation of the as cast structure into austenite may not take place at a time period of less than $2 \mathrm{hr}$ [12]. Austempering is usually performed at temperatures ranging between $260^{\circ} \mathrm{C}$ to $370^{\circ} \mathrm{C}$ [11].

Hence, In the present work, the optimum Austenitization temperature, Austempering temperature and time were selected based on the earlier studies.



Figure 1: Conventional Austempering Process.

\section{RESULTS}

\subsection{Microstructure}

The microstructure of the permanent moulded Nickel alloyed as cast ductile ironis analysed using optical microscope.

Figure $2 \mathrm{a}$ - $\mathrm{d}$ clearly shows the photomicrograph of as cast permanent moulded ductile iron samples alloyed with $0.5 \%, 1 \%, 1.5 \%$ and $2 \% \mathrm{Nickel}$ in etched condition $(200 \mathrm{X})$ using $2 \%$ nital solution. The graphite nodules are surrounded by ferrite in the form of "Bull's eye structure" plus pearlite and iron carbide $\left(\mathrm{Fe}_{3} \mathrm{C}\right)$.

Nickel additions had a significant effect on the pearlite and the ferrite content in the matrix. It is clear that the pearlite content in the matrix increased and the ferrite content decreased as the nickel additions were increased.

The nodule count of the samples and nodule size of the Nickel alloyed as cast ductile iron determined are clearly tabulated in the Table 2.

The photo micrograph of the Permanent moulded austempered structure alloyed with $0.5 \%, 1 \%, 1.5 \%$ and $2 \%$ nickel in etched condition (500X) using $2 \%$ Nital solution is clearly depicted in Figure 3 a-d.

Nickel additions had a significant effect on the morphology, retained austenite and the distribution of Bainite. PMADI sample alloyed with $0.5 \%$ and $1 \%$ Nickel revealed the presence of coarse distribution of Bainite with a retained austenite content of $27 \%$ and $30 \%$ and the same is clearly depicted in Figure 3 (a) and (b).

PMADI sample alloyed with $1.5 \%$ Nickel revealed the presence of feathery distribution of Bainite with a retained austenite content of $35 \%$. PMADI sample alloyed with $2 \%$ Nickel, the distribution of Bainite scatters and results in the formation of undissolved carbides with a retained austenite of about $31.5 \%$ and the same is clearly depicted in Figure 3 (c) and (d). 
Ductile Iron Using Single Edge Notch Bending Specimens

The microstructural observations of nodule count, nodule size and retained austenite of unalloyed and nickel alloyed PMADI samples are clearly depicted in Table 3.

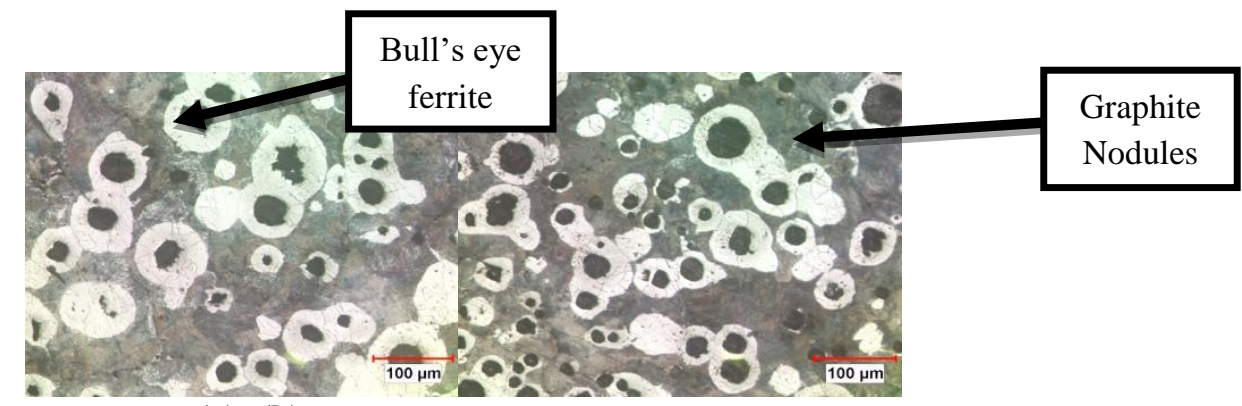

(a) (b)

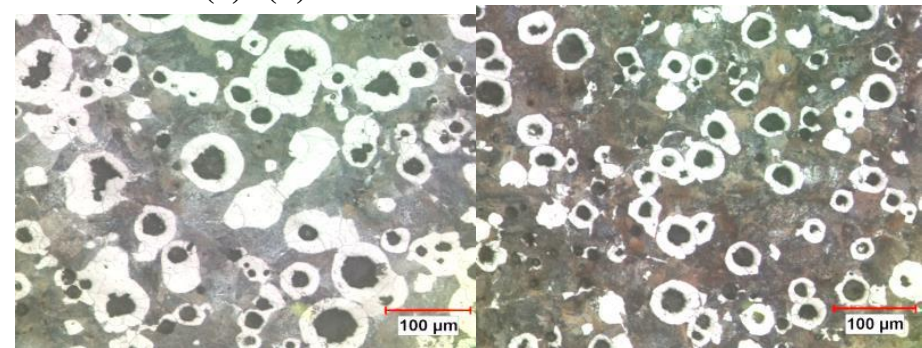

(c) (d)

Figure 2:a-d As - Cast Structure of 0.5\%, 1\%, 1.5\% and 2\% Ni Bearing Permanent Moulded Ductile Iron (200 X - Nital Solution).

Table 2: Nodule Count Details of As Cast Ductile Iron

\begin{tabular}{|c|c|c|}
\hline \multirow{2}{*}{ Casting Designation } & \multicolumn{2}{|c|}{ Graphite } \\
\cline { 2 - 3 } & Nodule Count $\left(\mathbf{N u m b e r} / \mathbf{m m}^{2}\right)$ & Nodule Size $(\boldsymbol{\mu m})$ \\
\hline Unalloyed- PMADI & 118 & $4-7$ \\
\hline PMADI - 0.5\% Ni & 130 & $5-7.5$ \\
\hline PMADI - $1 \% \mathrm{Ni}$ & 150 & $6-8.5$ \\
\hline PMADI - $1.5 \% \mathrm{Ni}$ & 200 & $8-10$ \\
\hline PMADI - $2 \% \mathrm{Ni}$ & 180 & $7-9$ \\
\hline
\end{tabular}

Table 3: Nodule Count Details of Alloyed PMADI Samples

\begin{tabular}{|c|c|c|c|}
\hline \multirow{2}{*}{ Casting Designation } & \multicolumn{3}{|c|}{ Graphite } \\
\cline { 2 - 4 } & Nodule Count $\left(\mathbf{N u m b e r} / \mathbf{m m}^{\mathbf{2}}\right)$ & Nodule Size (Ave) $(\boldsymbol{\mu m})$ & Retained Austenite (RA) (Vol \%) \\
\hline Unalloyed - PMADI & 200 & 6 & $23-25$ \\
\hline PMADI - 0.5\% Ni & 210 & 7 & $26-28$ \\
\hline PMADI - 1\% Ni & 250 & 7.5 & $29-31$ \\
\hline PMADI - 1.5\% Ni & 400 & 9 & $33-37$ \\
\hline PMADI - 2\% Ni & 300 & 10.5 & $30-33$ \\
\hline
\end{tabular}

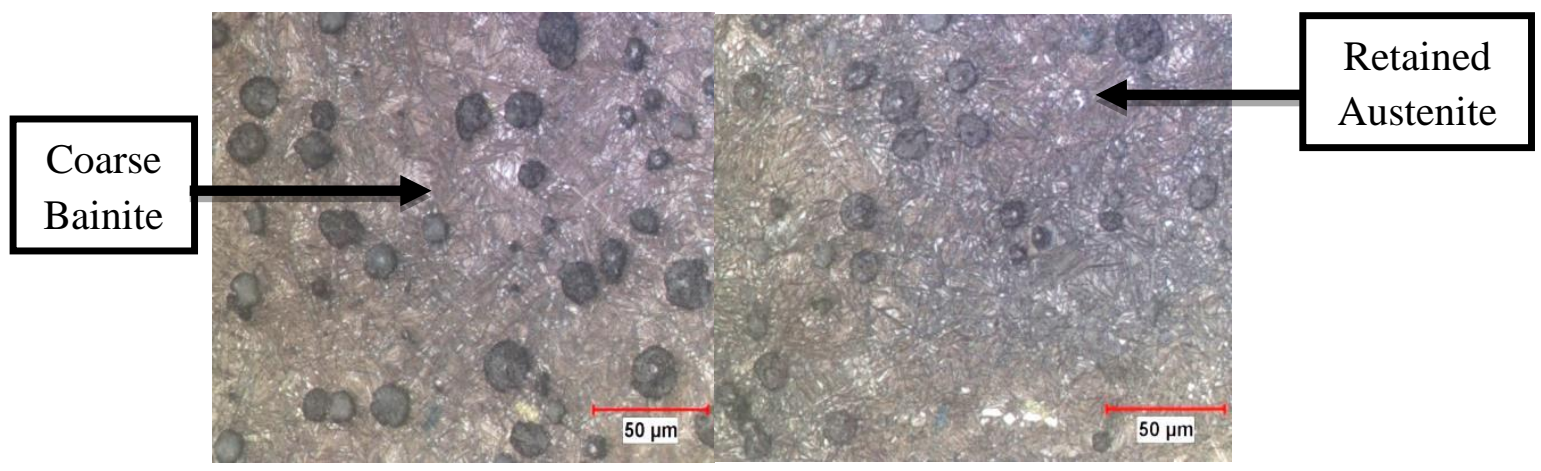

(a)

(b) 


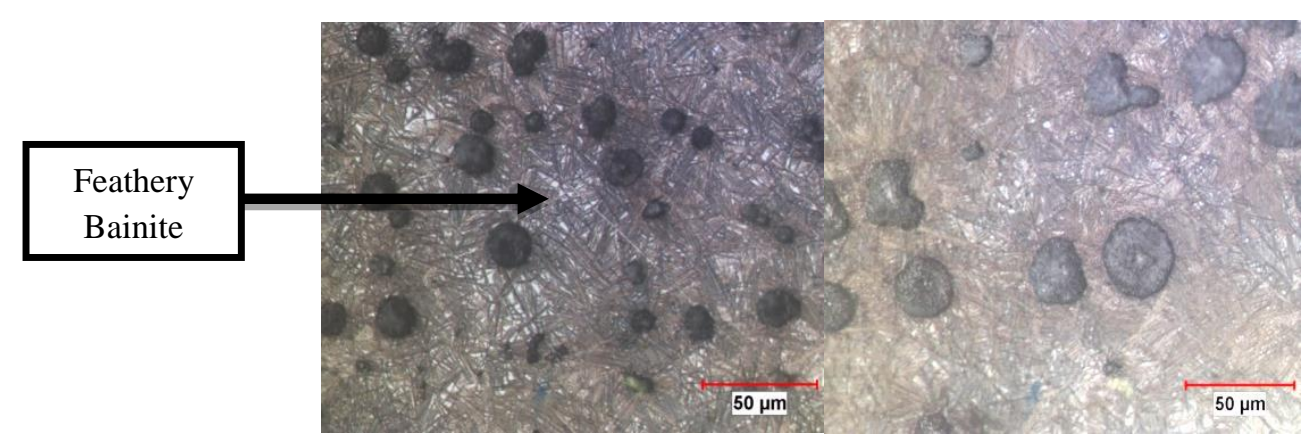

(c) (d)

Figure 3: a-d Austempered Structure of $0.5 \%, 1 \%, 1.5 \%$ and $2 \% \mathrm{Ni}$ Bearing Permanent Moulded Ductile Iron.

\subsection{XRD Analysis}

XRD analysis [18] is used to analyze the percentage of retained austeniteconsidering Nickel alloyed and un-alloyed PMADI samples. In the present investigation, Powder X-ray diffractometer (Bruker make) analysis using a monochromatic cu $\mathrm{K}_{\alpha}$ radiation was performed after the heat treatment process. XRD analysis was performed for un-alloyed and also for $0.5 \%, 1 \%, 1.5 \%$ and $2 \%$ Nickel alloyed PMADI samples austempered at $320^{\circ} \mathrm{C}$ for 120 Min duration and the detailed results of retained austenite (vol\%) are clearly tabulated in the Table 3.

\subsection{Fracture Toughness Test}

In the present investigation, Single edge notch Bending (SENB) specimens were prepared to investigate the plane strain fracture toughness of both unalloyed and Nickel alloyed PMADI samples as per ASTM standards.

The key dimensions are the crack length (a), width (w) and the span length (S). To ensure the plane strain condition, the specimen thickness (B) is sufficiently large in comparison with the plastic zone size. Specimen of size $50 \mathrm{~mm}$ X 25mm X 220mm, span $(S=4 \mathrm{w})=200 \mathrm{mmand}$ notch size of $20 \mathrm{~mm}$ and $22 \mathrm{~mm}$ is used as per ASTM standard ASTM E 399 [17] as depicted in Figure 4. For fracture toughness test, an average of two readings were recorded and reported.

Fatiguepre-cracking is done at a $\Delta \mathrm{K}$ level of 8 to $10 \mathrm{MPa} \sqrt{\mathrm{m}}$ using axial servo-hydraulic fatigue testing machine [INSTRON 8801] of capacity $100 \mathrm{kN}$ and the crack prepared was $1 \mathrm{~mm}$ for a/w ratio $=0.42$ and $1.5 \mathrm{~mm}$ for a/w ratio of 0.47. Extreme care should be taken to apply small levels of fatigue loading. The fracture toughness test was carried out on both unalloyed and Nickel alloyed PMADI samples. The specimens were subjected to three point bending test utilizing computerized universal testing machine (UTM) of $400 \mathrm{kN}$ capacity (Venus Instruments make).

Load vs Displacement curve were utilized for a/w ratio of 0.42 and 0.47 to record the reading of critical load $\left(\mathrm{P}_{\mathrm{q}}\right)$ and the same has been depicted in Figure 5. The Load vs Displacement curve recorded was Type III (17) curve for the fracture toughness testing of both unalloyed and Nickel alloyed austempered structure. Considering Type III curve, the critical load $\left(\mathrm{P}_{\mathrm{q}}\right)$ is equal to fracture load $\left(\mathrm{P}_{\mathrm{f}}\right)$.

Table 4 clearly depicts the experimental results of fracture load and fracture toughness of unalloyed and alloyed PMADI samples for a/w ratio of 0.42 and 0.47 .

Considering the dimensions as follows, 


$$
\begin{aligned}
& a=21 \mathrm{~mm}, w=50 \mathrm{~mm}, B=25 \mathrm{~mm}, S=4 w=200 \mathrm{~mm}\left(\text { For } \frac{a}{w}=0.42\right) \\
& a=23.5 \mathrm{~mm}, w=50 \mathrm{~mm}, B=25 \mathrm{~mm}, S=4 w=200 \mathrm{~mm}\left(\text { For } \frac{a}{w}=0.47\right)
\end{aligned}
$$

The Fracture Toughness ( $\left.\mathrm{K}_{\mathrm{IC}}\right)$ was evaluated utilizing the formula (1) and the experimental results are clearly tabulated in Table4.

$$
\begin{aligned}
& K_{I C}=\frac{P_{q} S}{B w^{\frac{3}{2}}} f_{2}\left(\frac{a}{w}\right) \\
& f_{2}\left(\frac{a}{w}\right)=\frac{3\left(\frac{a}{w}\right)^{\frac{1}{2}}\left(1.99-\frac{a}{w}\left(1-\frac{a}{w}\right)\left(2.15-3.93\left(\frac{a}{w}\right)+2.7\left(\frac{a}{w}\right)^{2}\right)\right)}{2\left(1+\frac{2 a}{w}\right)\left(1-\frac{a}{w}\right)^{\frac{3}{2}}}
\end{aligned}
$$

$f_{2}\left(\frac{a}{w}\right)$ is the geometry correction factor [17]

In the present investigation, the critical load $\left(\mathrm{P}_{\mathrm{q}}\right)$ is considered as maximum load in accordance with the ASTM standard ASTM E 399 [17]. All the validity conditions were then checked to confirm that "Candidate Fracture Toughness $\left(\mathrm{K}_{\mathrm{Q}}\right)=$ Material Fracture Toughness $\left(\mathrm{K}_{\mathrm{IC}}\right)^{\prime}$.

Figure 5 clearly depicts the Load Vs Displacement curve for PMADI sample alloyed with 0.5\%, 1\%, 1.5\% and $2 \% \mathrm{Ni}$ for a/w ratio of 0.42 utilizing computerized universal testing machine (UTM). It was found that as load increases the elongation also increases. The maximum displacement recorded was $1.3 \mathrm{~mm}$ for PMADI alloyed with $1.5 \% \mathrm{Ni}$. The same procedure was repeated for a/w ratio of 0.47 .

Figure 6 shows clearly depicts the variation of fracture toughness of Nickel alloyed PMADI samples considering $\mathrm{a} / \mathrm{w}$ ratio of 0.42 and 0.47 . It is clear that, the load carrying capability decreases, as a/w ratio increases and also PMADI sample alloyed with $1.5 \%$ Nickel showed the maximum peak load and superior value of fracture toughness in comparison with PMADI sample alloyed with $0.5 \%, 1 \%$ and $2 \%$ Nickel for a/w ratio of 0.42 and 0.47 . The very fine distribution of Bainite and the presence of retained austenite (vol\%) was responsible for the enhancement of fracture toughness. 


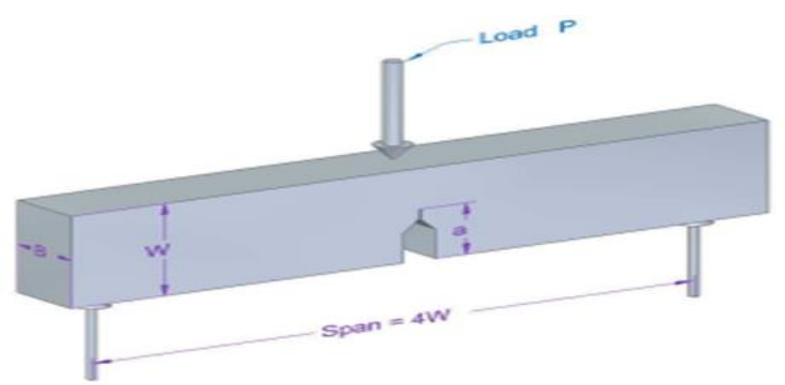

Figure 4: SENB Specimen.

Table 4: Experimental Fracture Toughness results for Austempered Samples

\begin{tabular}{|c|c|c|c|c|}
\hline \multicolumn{2}{|c|}{ a / w ratio $=\mathbf{0 . 4 2}$} & \multicolumn{2}{c|}{ a / watio $=\mathbf{0 . 4 7}$} \\
$\begin{array}{c}\text { Casting } \\
\text { Designation }\end{array}$ & $\begin{array}{c}\text { Fracture Load } \\
\left(\mathbf{P}_{\mathbf{q}}\right) \mathbf{~ k N}\end{array}$ & $\begin{array}{c}\text { Fracture Toughness }\left(\mathbf{K}_{\mathbf{I C}}\right) \\
\mathbf{M P a} \sqrt{\mathbf{m}}\end{array}$ & $\begin{array}{c}\text { Fracture Load } \\
\left(\mathbf{P}_{\mathbf{q}}\right) \mathbf{k N}\end{array}$ & $\begin{array}{c}\text { Fracture Toughness }\left(K_{I C}\right) \\
\mathbf{M P a} \sqrt{\mathbf{m}}\end{array}$ \\
\hline Unalloyed - PMADI & 50.36 & 75.66 & 42.67 & 74.14 \\
\hline PMADI - 0.5\% Ni & 52.84 & 79.39 & 44.98 & 78.15 \\
\hline PMADI - 1\% Ni & 53.89 & 80.97 & 45.66 & 79.33 \\
\hline PMADI - 1.5\% Ni & 59.13 & 88.68 & 50 & 87.24 \\
\hline PMADI - 2\% Ni & 57.12 & 85.82 & 48.52 & 84.30 \\
\hline
\end{tabular}

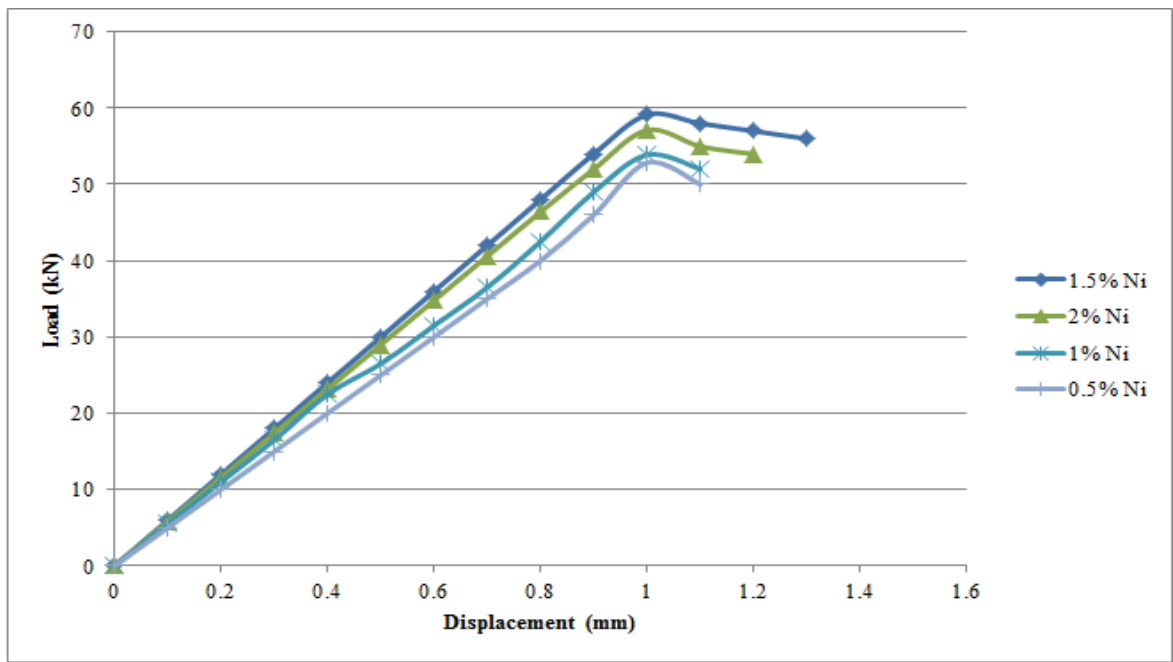

Figure 5: Load Vs Displacement Curve for a/w ratio of 0.42.

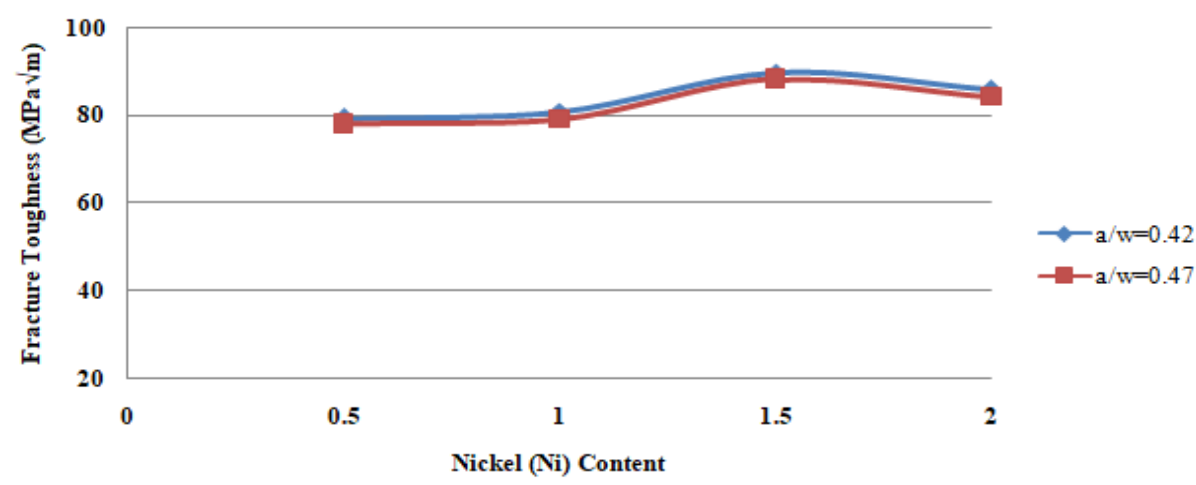

Figure 6: Variation of Fracture Toughness for Nickel Alloyed PMADI Samples.

\subsection{Effect of a/w ratio-ANSYS}

Considering the a/w ratio of 0.42 and PMADI $-1.5 \% \mathrm{Ni}$, The young's modulus (E) was found to be $156 \mathrm{GPa}$ utilizing tensile test experiment as per ASTM standard E8M specifications. 

Ductile Iron Using Single Edge Notch Bending Specimens

Figure 7 clearly depicts the modelling, meshing, Boundary conditions and load details of SENB specimen. Element type - PLANE 82 is utilized to analyse the stress distribution and also the effect of a/w ratio.

Considering 1.5\% Nickel alloyed PMADI sample and selecting a peak load of $59.13 \mathrm{kN}$ from the Table4, the maximum stress was found to be $1341 \mathrm{MPa}$ around the region of crack and the same was clearly depicted in the Figure 8.

In the present investigation, the effect of different a/w ratio was also studied utilizing ANSYS as a software considering 1.5\% Ni PMADI sample. The peak load considered for the different a/w ratio of $0.38,0.42,0.47$ and 0.50 was $59.13 \mathrm{kN}$.

The maximum stress distribution plot of $1.5 \% \mathrm{Ni}$ alloyed PMADI sample for different a/w ratio is clearly depicted in the Figure 9, 10, 11 and 12. From the stress plot, It is clear that, the maximum stress was found to be around the region of crack.

As the a/w ratio Increases, the maximum stress increases and the load carrying capacity decreases.



Figure 7: Modelling, Meshing and Load Details of SENB Specimen.


Figure 8: Von-Mises Stress Plot for PMADI-1.5\% Ni.
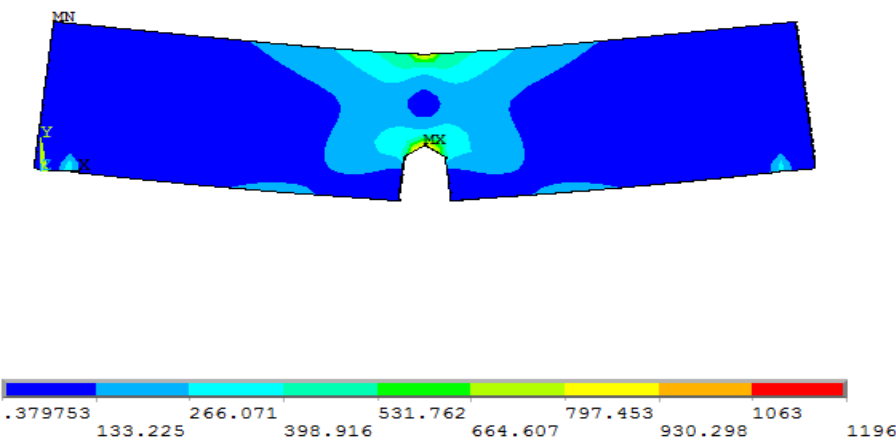

Figure 9: Von-Mises Stress Plot for a/w ratio of 0.38 . 

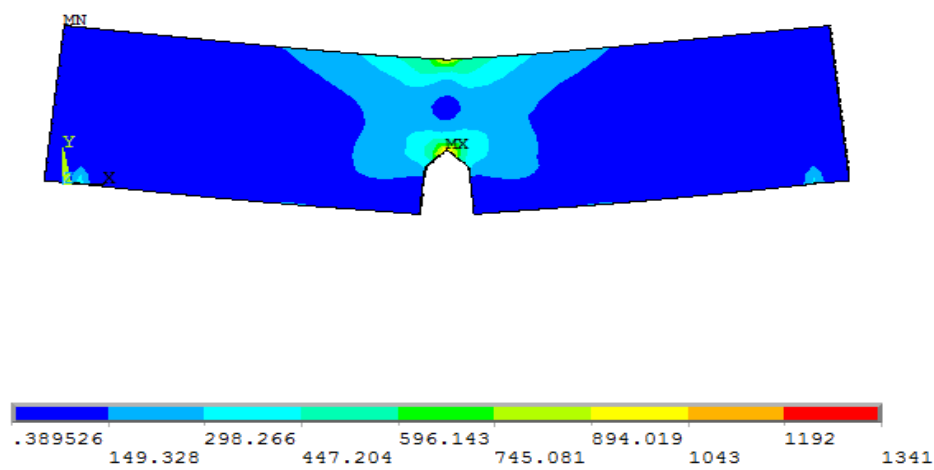

Figure 10: Von-Mises Stress Plot for a/w ratio of 0.42 .
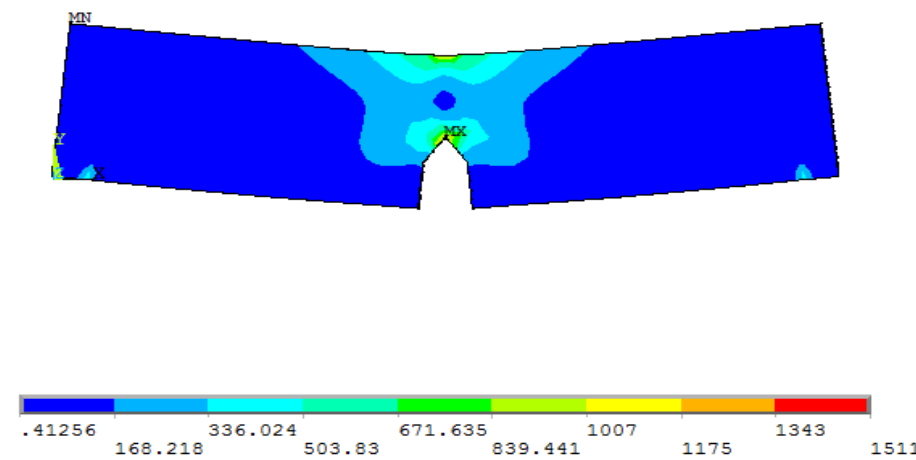

Figure 11: Von-Mises Stress Plot for a/w ratio of 0.47.


Figure 12: Von-Mises Stress Plot for a/w ratio of 0.50.

\subsection{Hardness Test}

Hardness test is conducted utilizing Brinell hardness tester (Venus Instruments make - VAB - 250) with applied load of $250 \mathrm{Kgf}$ as per ASTM standards ASTM E10-18for the Nickel alloyed PMADI samples austempered at $320^{\circ} \mathrm{C}$ for 120 Min duration. Three readings were taken for each specimen and the results were averaged and the same was clearly depicted in Table 5 .

The Ball Indenter diameter (D) of $5 \mathrm{~mm}$ and dwell time of 15 Seconds was considered for all the samples. The indentation diameter (d) was analysed utilizing Brinell microscope with the help of the indentation created on the specimen.

The Brinell hardness number was evaluated as per ASTM standard ASTM E10 - 18 by utilizing the equation (2) 


$$
B H N=\frac{2 F}{\pi X D\left(D-\sqrt{D^{2}-d^{2}}\right)}
$$

Table 5: Hardness Test Results

\begin{tabular}{|c|c|c|}
\hline Casting Designation & Avg Indentation Dia (d) $\mathbf{~ m m}$ & Brinell Hardness Number (BHN) \\
\hline PMADI - 0.5\% Ni & 0.90 & 389.62 \\
\hline PMADI - $1 \% \mathrm{Ni}$ & 0.94 & 356.86 \\
\hline PMADI - $1.5 \% \mathrm{Ni}$ & 1.05 & 285.48 \\
\hline PMADI - 2\% Ni & 1 & 314.86 \\
\hline
\end{tabular}

From the Hardness test results depicted in the Table 5, the maximum hardness was found to be for PMADI sample alloyed with $0.5 \% \mathrm{Ni}$.

\section{FRACTOGRAPHY STUDIES}

In the present investigation, the fracture surfaces were examined on a Hitachi S 3500 Model scanning electron microscope (SEM) using an accelerating voltage of $10 \mathrm{kV}$ to determine the failure mode. Figure 13 (a) exhibits the fracture surface morphology ofPMADI-1.5\% Ni austenitized at $912^{\circ} \mathrm{C}$ for $2 \mathrm{hrs}$, austempering temperature $320^{\circ} \mathrm{C}$ for 120 Min duration indicated ductile fracture due to the presence of large number of knots. These features indicates the improved fracture toughness characteristics achieved for the PMADI - $1.5 \% \mathrm{Ni}$ sample.

Figure 13 (b) exhibits the fracture surface morphology of PMADI $-0.5 \% \mathrm{Ni}$ austempered at $320^{\circ} \mathrm{C}$ for $120 \mathrm{Min}$ duration indicated brittle fracture as the value of Hardness is more and also due the presence of less number of knots.

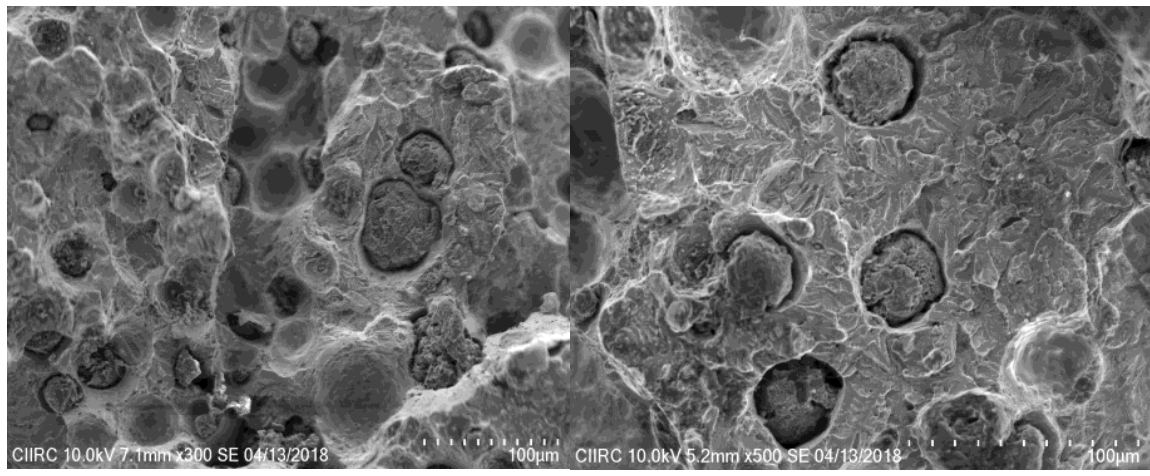

(a)

(b)

Figure 13: SEM Photomicrograph of Fractured SENB Surfaces of (a) PMADI-1.5\% Ni (b) PMADI-0.5\% Ni

\section{DISCUSSIONS}

Kobayashi et al. [19] reported that, addition of Nickel enhances micro segregation around the graphite nodules and increases the stability of the retained austenite in the final microstructure. This factor may have resulted in higher percentage of retained austenite due to Nickel additions, resulting in a major benefit for PMADI samples to enhance the fracture toughness characteristics.

Kobayashi and Tachibana [20] reported that, the addition of Nickel favours toughened Bainite phase and the retained austenite phase is stabilized. The diffusion of Nickel into austenite phase takes place during holding in the ( $\alpha$ Ferrite $+\gamma$ - Austenite) temperature range.

The role of nickel as an alloying element is known to strengthen the Bainitic matrix and stabilize the austenite 
phase and hence, the present work is focussed on the detailed investigation of fracture toughness characteristics of PMADI samples alloyed with Nickel. The results were analysed based on graphite morphology and Bainitic matrix.

Permanent moulds offers better advantages in terms of excellent dimensional stability and also the graphite nodules are denser in comparison with sand moulds. Hence, In the present investigation permanent moulds were selected to analyse the fracture toughness characteristics.

The utilization of permanent moulds, higher nodule size and upper Bainite transformation[Figure 3 (c)] favoured the fracture toughness of $1.5 \%$ Nickel bearing PMADI sample.

Fracture toughness values were determined from the critical load $\left(\mathrm{P}_{\mathrm{q}}\right)$ values in accordance with the ASTM standards (ASTM E399). The maximum fracture load and maximum fracture toughness was found to be maximum for $1.5 \%$ Nickel PMADI sample considering $\mathrm{a} / \mathrm{w}$ ratio of 0.42 and 0.47 .

Considering 1.5\% Nickel alloyed PMADI sample the volume fraction of retained austenite increases in comparison with unalloyed PMADI sample and the same was clearly depicted in the Table3. The proper Nickel addition to the base iron increases the stability of the retained austenite and the same was correlated well with the literature. [14]

Considering 2\% Nickel PMADI sample, the sudden drop in the level of retained austenite and ferrite content was observed and the same can be attributed due to the decreased rate of diffusion of $\mathrm{c}$ arbon from ferrite to austenite. [Table3]

As the volume of retained austenite decreases, the value of hardness increases and the same can be attributed due to the presence of lower Bainite and the same was correlated well with the microstructure [Figure 3 (a) and (b)].

The fracture toughness increases as hardness decreases and the same can be attributed due to the presence of upper Bainite (feathery Bainite) and the same was correlated well with the microstructure [Figure 3 (c)].

From the outcome of the fracture toughness testing, The fracture toughness characteristics of PMADI sample alloyed with $1.5 \%$ Nickelproduced by the conventional austempering process was increased due to the effect of finer Bainite distribution, well formed nodule distribution and the presence of retained austenite.

PMADI sample alloyed with $0.5 \%$ Nickel showed less value of fracture toughness. The presence of coarse Bainite[Figure 3 (a)] reduces the fracture toughness of the PMADI sample.

$2 \%$ Nickel bearing PMADI sample resulted in lower value of fracture toughness in comparison with $1.5 \%$ Nickel bearing PMADI sample due to the precipitation of un-dissolved carbides in the matrix[Figure3 (d)].

Alloyed PMADI sample showed higher value of fracture toughness in comparison with Un-alloyed PMADI sample and the same was increased due to the increased volume fraction of retained austenite[Table3] in the matrix of $1.5 \%$ Nickel bearing PMADI sample.

Summarizing the present work, addition of $1.5 \%$ Nickel improved the fracture toughness characteristics of PMADI sample in comparison with $0.5 \%, 1 \%$ and $2 \%$ Nickel alloyed PMADI samples.

Thus the advantages of PMADI castings having superior strength, Impact toughness boosted by an increase in the fracture toughness and addition of Nickel as alloying element helps to exploit the usefulness in the automotive, power plants and mining applications. 


\section{CONCLUSIONS}

- The PMADI sample alloyed with $1.5 \%$ Nickel austempered at $320^{\circ} \mathrm{C}$ for 120 Min duration reveals the presence of feathery distribution of Bainite and maximum percentage of retained austenite. These factors make a suitable candidate for the application requiring superior fracture toughness to resist catastrophic failure in the presence of crack.

- The maximum fracture toughness of $1.5 \%$ Nickel bearing PMADI sample is found to be $12 \%$ more in comparison with $0.5 \%$ Nickel bearing PMADI sample and $10 \%$ more in comparison with $1 \%$ Nickel bearing PMADI sample.

- The maximum fracture toughness of $1.5 \%$ Nickel bearing PMADI sample is found to be $17 \%$ more in comparison with unalloyed PMADI sample austempered under similar conditions.

\section{ACKNOWLEDGEMENT}

The authors wished to acknowledge Jyothy Institute of Technology \&Sophisticated Instrument facility (SIF), CIIRC Bengaluru and Atria Institute of Technology, Bengaluru for granting permission to present this paper.

\section{REFERENCES}

1. O.Eric, M.Jovanovic, L.Sidjanin, D.Rajnovic, Microstructure and mechanical properties of Cu Ni Mo Austempered Ductile Iron, Journal of mining and metallurgy, 40B (1) (2004) 11-19.

2. J Zimba, D.J Simbi, E Navara, Austempered Ductile Iron : an alternative material for Earth moving components. cement and concrete composite, Volume 25, Issue 6, August 2003, Pages 643 - 649.

3. Susil K Putatunda, Sharath Kesani, Ronald Tackett, Gavin Lawes, Development of Austenite free ADI (Austempered Ductile Iron), Materials science and Engineering: A, 435 - 436, $5^{\text {TH }}$ November 2006, Pages 112 - 122.

4. S. Seetharamu, P.Sampathkumaran, R.K.Kumar, K.NarasimhaMurthy and P.Martin Jebraj, Abrasion and erosion behaviour of permanent moulded ADI, Wear, 163, 1993, Pages 1 - 8.

5. K.B.Rundman, Austempered ductile iron: Striving for continuous improvement, Proceedings of the 1991 world conference on Austemepered ductile iron, March 12-14, 1991, Indian Lakes Resort, Bloomingdale (Chicago), IL (1991), pp. 1 - 21.

6. A.A.Abioye, P.O.Atanda, O.P.Abioye, S.A. Afolalu and J.O.Dirisu, Microstructural characterization and some mechanical behaviour of low manganese austempered ferritic ductile iron, International Journal of Applied Engineering research, ISSN 0973 -4562, Volume 12, Number 23 (2017), PP 13435 - 13441.

7. Jiwang Zhang, Ning Zhang, Mintang Zhang, LiantaoLu, DongfangZeng, Qingpeng Song, Microstructure and mechanical properties of austempered ductile iron with different strength grades, Materials letter, Elsevier, Volume 119, 15 ${ }^{\text {th }}$ March 2014, Pages 47-50.

8. S.K.Swain, R.K Panda, J.P Dhal, S.C.Mishra and S.Sen, Phase Investigation of Austempered Ductile Iron, Orissa Journal of Physics, Vol.19, No.1, Feb.2012, PP 73 - 80.

9. Ananda Hegde, Sathyashankara Sharma, Ramakrishna Vikas Sadanand, Mechanical characterization and optimization of heat treatment parameters of manganese alloyed austempered ductile iron, Journal of Mechanical Engineering and Sciences, ISSN: 2289 - 4659, Volume 13, Issue 1, PP. 4356-4367, March 2019.

10. T.R.Uma, J.B.Simha, K.Narasimha Murthy, Influence of nickel on mechanical and slurry erosive wear behaviour of permanent moulded toughened austempered ductile iron, Wear, Volume 271, Issues 9-10, 29 July 2011, Pages 1378 - 1384.

11. K.Narasimha Murthy, P. Sampathkumaran, S. Seetharamu, Abrasion and erosion behaviour of manganese alloyed permanent 
moulded Austempered Ductile Iron, Wear, 267 (2009), Pages 1393 - 1398.

12. Susil K Putatunda, Pavan K Gadicherla, Influence of austenitizing temperature on fracture toughness of a low manganese austempered ductile Iron (ADI) with ferritic as cast structure, Elsevier, Materials science and Engineering: A268 (1999), 15 - 31

13. T.L Anderson, Fracture Mechanics - Fundamentals and Applications, 3rd edn. (Taylor and Francis Group, New York, 2013).

14. Ayman H Elsayed, M.M Megahed, A.A Sadek, K.M.Abouelela, Fracture toughness Characterization of ADI produced using both conventional and two step Austempering process, Journal of Materials and Design, 30(2009), 1866 - 1877.

15. Peng-yue Yi, Er-Jun Guo, Li-ping Wang, Yi-cheng Feng, Chang-Liang Wang, Effect of cu content on microstructures and mechanical properties of ADI treated by two-step austempering process, China Foundry, May 2019, volume 16, Issue 3, PP $168-176$

16. K S Ravishankar, P.P Rao, K.R.Udupa, Improvement in Fracture Toughness of austempered ductile iron by two-step austempering process, International Journal of cast Metals Research, Taylor and Francis Group; ISSN:1364-0461, Volume 23, 2010 - Issue 6, Pages 330 - 343.

17. ASTM Standards, Standard Test Method for Plane-Strain Fracture Toughness of Metallic Materials (ASTM International, E 399-17, 2017).

18. ASTM E1245-03 (2016) Standard practice for determining the inclusion of second-Phase constituent of metals by automatic image analysis, ASTM International, West Conshohocken, PA, 2016.

19. T. Kobayashi, H. Yamamoto, S. Yamada, On the toughness and fatigue properties of Austempered ductile cast iron, Proceedings of the 1991 world conference on Austempered ductile iron, March 12-14,1991, Indian Lakes Resort, Bloomingdale (Chicago), IL (1991).

20. Toshiro Kobayashi, Hitoshi Tachibana, Strengthening and toughening of Ni added ductile cast iron by heat treatment in the eutectoid temperature range, Transactions of the Japan Institute of Metals, 24 (5) (1983), PP. 281-292.

21. ANSYS Help file version 16.0. 